\title{
Solar Electric Power System Analyses for Mars Surface Missions
}

Thomas W. Kerslake and Lisa L. Kohout

Glenn Research Center, Cleveland, Ohio

Prepared for the

34th Intersociety Energy Conversion Engineering Conference sponsored by the Society of Automotive Engineers

Vancouver, British Columbia, Canada, August 1-5, 1999

National Aeronautics and

Space Administration

Glenn Research Center 


\section{Acknowledgments}

The authors wish to acknowledge and thank: Mr. Leonard Dudzinski and Mr. Leon Gefert of the NASA Glenn

Research Center for making the EPS CAD drawings and performing the Earth-Mars trajectory analysis, respectively, and Mr. Jeffrey George and Mr. Todd Peters of the NASA Johnson Space Center for developing the power requirements and ISRU plant power utilization strategy.

This report contains preliminary

findings, subject to revision as analysis proceeds.

Available from

NASA Center for Aerospace Information

7121 Standard Drive

Hanover, MD 21076

Price Code: A03
National Technical Information Service 5285 Port Royal Road Springfield, VA 22100

Price Code: A03 


\title{
Solar Electric Power System Analyses for Mars Surface Missions
}

\author{
Thomas W. Kerslake and Lisa L. Kohout \\ National Aeronautics and Space Administration \\ Glenn Research Center \\ Cleveland, Ohio 44135
}

\begin{abstract}
The electric power system is a crucial element of any architecture supporting human surface exploration of Mars. In this paper, we describe the conceptual design and detailed analysis of solar electric power system using photovoltaics and regenerative fuel cells to provide surface power on Mars. System performance, mass and deployed area predictions are discussed along with the myriad environmental factors and trade study results that helped to guide system design choices. Based on this work, we have developed a credible solar electric power option that satisfies the surface power requirements of a human Mars mission. The power system option described in this paper has a mass of $\sim 10$ metric tons, a 5000-m2 deployable photovoltaic array using thin film solar cell technology.
\end{abstract}

\section{INTRODUCTION}

The electric power system (EPS) is a crucial element of any human Mars surface exploration mission architecture. The bulk of power generated will be delivered to crew life support systems, extravehicular activity suits, robotic vehicles and pre-deployed in-situ resource utilization (ISRU) equipment. Before the crew departs for Mars, the ISRU plant operates for 435 days producing liquefied methane and oxygen for ascent stage propellants and water for crew life support. About 200 days after ISRU production is completed, the crew arrives for a 500-day surface stay. In this scenario, the EPS must operate for a total of 1130 days (equivalent to 1100 Martian "sols"). To support these loads, roughly 40 $\mathrm{kW}$ of continuous day-night power would be required. In the past, nuclear dynamic systems were proposed to meet power requirements [1]. A nuclear reactor system has the advantages of compactness, ease of packaging and insensitivity to environmental factors, i.e. availability of sunlight.
In support of a non-nuclear mission architecture, a photovoltaic (PV) power generation system with regenerative fuel cell (RFC) energy storage has been under study at NASA. In the past, PV/RFC designs proposed have had unwieldy masses, stowed volumes and deployed PV areas [1]. These unfavorable results were strongly driven by point designs that satisfied continuous power requirements with pessimistic insolation assumptions and bulky solid panel PV arrays. In the current study, we have revised the design/analysis process as follows: (1) intelligently reallocated electrical loads as a function of day, night, clear sky and dust storm conditions, (2) conducted detailed performance analyses to ensure mission power requirements are satisfied throughout the mission with a minimum size EPS and (3) employed mass/volume efficient, thin membrane PV arrays with tent-like structures and thin film solar cells [2,3].

In this paper, we describe the conceptual design and detailed analysis of a PV/RFC-based EPS to provide surface power for human on Mars. EPS performance, mass and deployed area predictions are discussed along with environmental factors and trade study results that helped to guide system design choices.

\section{MARS ENVIRONMENTS}

Mars environments strongly influence the design and operation of surface power systems [4,5]. Foremost of these influences is atmospheric dust. Airborne dust particles scatter and absorb solar wavelength radiation to affect the magnitude, angular distribution and spectrum of solar insolation. These effects are most pronounced during great dust storms (with an area $>10^{6} \mathrm{~km} 2$ ) with durations over 100 days and peak opacity (or optical depth (OD)) greater than 6 . These storms occur with a yearly probability of $30 \%$ to $80 \%[6,7]$. Local dust storms (with an area $<10^{6} \mathrm{~km} 2$ ) occur with $5 \%$ probability in Mars equatorial regions and have only a minor impact on 
seasonal insolation due to their limited size, duration (a few days) and moderate OD $(-1)[8]$. Sunlight is also obscured by dust hazes, ground fogs (specific to site and local weather), $\mathrm{CO} 2$ and water ice clouds [9]. These clouds do not greatly affect mid-latitude seasonal insolation due to their limited size and abundance at higher latitudes and higher OD values. Under clear skies following dust storm activity, dust particles precipitate and collect on surfaces reducing the transmission of light (harmful to PV arrays) [10] and decreasing surface radiative emission (harmful to heat rejection radiators) [5]. Solar cell current loss from dust precipitation, $0.28 \%$ per sol, was measured over a short period of time in 1997 during the Pathfinder Mission [11,12].

Other important environmental effects are low temperatures, wind and electrostatic charging. Typical operating temperatures for large-area, deployed PV arrays will range between $-100^{\circ} \mathrm{C}$ and $0^{\circ} \mathrm{C}$. These low temperatures affect material properties and solar cell performance [13]. Wind speeds in the upper atmosphere can exceed $100 \mathrm{~m} / \mathrm{sec}$ [14]. However, on the Martian plains, the Viking landers measured typical wind speeds of 2-7 m/sec and wind gusts up to only $26 \mathrm{~m} / \mathrm{sec}$ at an elevation of $1.6 \mathrm{~m} \mathrm{[15].} \mathrm{Over} \mathrm{the} \mathrm{surface} \mathrm{of} \mathrm{a} \mathrm{large,}$ elevated PV array in the boundary layer, dust storm peak wind speeds could range from $3 \mathrm{~m} / \mathrm{sec}$ at the surface to about $55 \mathrm{~m} / \mathrm{sec}$ at the top (about 5-m elevation). Future landing sites may have topographical features that disturb the velocity boundary layer thereby accentuating or ameliorating local wind velocities. With an atmospheric pressure of only 6 torr, PV array aerodynamic loading estimates are modest in high winds, i.e. about twice the body force, with proper design. The dry, low pressure atmosphere of Mars is also conducive to electrostatic charging. Paschen discharge voltage is thought to be as low as $100 \mathrm{~V}$ [16]. PV arrays, radiators and associated deployment equipment (articulating structures, rovers, etc.) are likely to become triboelectrostatically charged via moving surface contact and impingement of wind born dust/sand particles.

The Mars atmosphere is thick enough to provide effective shielding from meteors and solar proton/electron radiation [17,18]. Galactic cosmic radiation will not be attenuated by the Mars atmosphere but the accumulated dose in solar cells is negligible. Therefore, from the standpoint of PV array performance degradation, radiation damage and meteor impact damage can be neglected. Designs must still, however, afford radiation protection for human crews and electronics.

\section{EPS DESIGN}

Based on engineering judgement and trade studies (discussed below), a conceptual EPS design was developed. This design, deployed on the Martian surface with an ISRU landing vehicle, is shown from several views in Figure 1. The design is dominated by the 5000-m2-class PV array that is deployed orthoginally as four tent structures. Each tent structure is approximately $5-\mathrm{m}$ on a side and $100-\mathrm{m}$ long. The structure is comprised of composite members [19] and is deployed by an articulating mast [20], an inflatable boom or by rover vehicles and subsequently anchored to the ground. The array must be deployed over a bounder field terrain with the attendant rock size and terrain slope distributions [14,21]. The tent sides form a $45^{\circ}$ angle with the ground. This angle was selected to provide good aeolian and gravity assisted dust removal [22-24], good structural stiffness and strength and reasonably good Sun angles. Tent structures in general respond favorably to Martian wind loading. Net structure forces are downward resulting in compressive stresses and reduced bending moments [19]. Array structures and membranes must also accommodate structural, thermal and dust loadings from a near-by, descent vehicle landing.

Array membranes consist of perimeter-reinforced, 2-mil thick polyimide membrane with thin film, 3 -junction, $5 \times 5$ $\mathrm{cm}$ amorphous silicon-germanium (a-SiGe) solar cells [25]. The thin film cells are encapsulated with 1.5-mil thick FEP Teflon for isolation from the ambient environment. For electrostatic charge control and scratch resistance, array surfaces are coated with a transparent conducting metal film (i.e., InSnO2) and bonded to metal discharge points located on the structure [16]. In stowed configuration, the membranes are either rolled on a mandrel or fan-folded within a containment structure. In both cases, thin film cell minimum bend radius and mechanical strain limits are not exceeded [26-29]. In deployed configuration, membranes are tensioned to create a $10^{\circ}$ catenary angle (see Figure 1c). Membranes are not populated with solar cells within $\sim 0.5 \mathrm{~m}$ above the surface to avoid being covered by saltating grains of soil [22]. As a more advanced solar cell option, CulnS2 thin films [30-32] or CulnGaSe2 thin films [33] could be substituted for the aSiGe film. This array membrane technology is common with that proposed for the human Mars mission, solar electric propulsion stage power system [34].

The PV array is divided into 8 independent electrical sections, each comprising one side of a tent structure. Array strings contain a sufficient number of seriesconnected cells to provide $600^{+}$volts maximum power voltage at end-of-life. By-pass diodes are not incorporated into the most recent string design, but have not been ruled out as means to reduce potential array long-term degradation. The number of parallel strings is selected to meet power requirements. PV array designs incorporate a flat copper multi-ribbon power harness encapsulated in polyimide. Conductor cross section was sized to provide a $3 \% \Delta \mathrm{V} / \mathrm{V}$. 
Other surface PV array conceptual designs have been developed [35] but will not be discussed in this paper. Sun-tracking PV array designs were not considered due to increased complexity and mass for a marginal gain performance $(13 \%-19 \%)[36]$.

The RFC is based on hydrogen-oxygen, proton exchange membrane fuel cell and electrolyzer technology [3]. The fuel stack consists of 115 cells, each $0.2-\mathrm{m}$ square $(0.02 \mathrm{~m} 2$ active area), operated at $60 \mathrm{psi}$, $80^{\circ} \mathrm{C}$ and a nominal 500 amps/ft2 current density. Seven stacks are series connected consistent with the $600-\mathrm{V}$ primary voltage level and include by-pass diodes. The electrolyzer stack consists of 100 cells, each $0.27 \mathrm{~m}$ $\times 0.34 \mathrm{~m}$ (0.023 $\mathrm{m} 2$ active area), operated at $315 \mathrm{psi}$ and a nominal current density of $200 \mathrm{amps} / \mathrm{ft} 2$. A paralleled pair of four, series-connected stacks is required to attain the proper current and voltage levels. The hydrogen and oxygen reactants are stored in gaseous form at $3000 \mathrm{psi}$ while the water is stored at 14.7 psi. Hydrogen is contained in two spherical tanks constructed of Kevlar with a 10-mil titanium liner to minimize gas diffusion. Single tanks of the same construction are used to contain the oxygen and water. Tank diameters and wall thicknesses are chosen consistent with the RFC energy storage capacity requirement and to provide safe operating stresses. Fuel cell operating temperature is maintained by a $\sim 40 \mathrm{~m} 2$, deployable, pumped-fluid loop radiator using water as the working fluid. Radiator mass, including pump and flow control equipment, is estimated at $6 \mathrm{~kg} / \mathrm{m} 2$. For mass estimates, fuel cell and electrolyzer ancillary equipment is included to account for fluid lines, pumps, valves, structure and controllers. Reactant compressor mass and parasitic power characteristics were not included in this study, but will be incorporated in the next design iteration.

The EPS employs a channelized, 600-Vdc, power management and distribution (PMAD) architecture featuring 8 channels (see Figure 2). Each of eight PV array sections has an array regulator unit (ARU) that feeds power to a central direct current switching unit (DCSU). The ARU uses coarse and fine switching, sequential shunts (field effect transistors) to maintain a set point output voltage and to dissipate unneeded array power. The ARU also contains input/output filtering to control electrical noise from switching and from electrostatic discharges. The DCSU switches power from the arrays, the RFC and loads. RFC operation is managed by a charge/discharge unit (CDU) that controls input/output currents and voltages. The DCSU output feeds paralleled, dc-to-dc converter units (DDCUs) that transform the voltage level from $600 \mathrm{~V}$ to $120 \mathrm{~V}$. Each DDCU feeds paralleled remote power control (RPCs) that provide on/off switching at the load and currentlimiting fault protection. RPCs feed power to output panels (OPs) that provide the plug-in interface for loads within crew habitats. Lastly, remote bus isolator (RBI) relays are located between each PMAD component to provide automatic, fault current protection. RBls may include manual over-ride switching to allow for maintenance or change-out. For a pre-deployed ISRU plant, DDCUs and OPs may not be required.

The 600-V primary PMAD voltage was selected for two reasons. First, 600-V silicon and silicon-carbide based technology development is well underway at NASA for switch gear components and remote power controllers [37]. And second, the high voltage reduces conductor current density allowing use of smaller gage, less massive conductors. Yet the voltage level is low enough to still allow use of standard mil-spec aerospace power cabling. Gage 0, 4, 12 and 30 copper conductors with Teflon type insulation were used throughout the PMAD system. Conductor gages were selected as a compromise between voltage drop and mass while satisfying derated current limits. Most cable runs are on the order of $10-\mathrm{m}$ in length. The exception is a $200-\mathrm{m}$ cable between the DCSU, on the ISRU lander, and DDCUs in the surface habitat module, assumed to be precision landed 200-m distant from the ISRU lander. For comparison, the Apollo 12 Lunar Module touched down $155-\mathrm{m}$ from the Surveyor III spacecraft that had landed 31-months earlier [38]. To save mass, the next power cable design iteration will include aluminum conductors.

\section{EPS MASS ESTIMATES}

PV array mass estimates are based on a calculated membrane mass using specified layer thicknesses and material densities. This mass calculation includes encapsulant, adhesive, cell contacts and interconnects, and substrate. Launch containment structures, deployment structures and/or inflation/rigidization equipment are assumed four times as massive as the $\sim 0.2 \mathrm{~kg} / \mathrm{m} 2$ membrane mass [35]. The power harness mass is based on that for the International Space Station (ISS) PV array and scaled with conductor current level.

Masses for the ARU $(2.5 \mathrm{~kg} / \mathrm{kW})$, DCSU $(3 \mathrm{~kg} / \mathrm{kW})$, CDU $(2.7 \mathrm{~kg} / \mathrm{kW}), \mathrm{DDCU}(8 \mathrm{~kg} / \mathrm{KW}), \mathrm{RPC}(0.6 \mathrm{~kg} / \mathrm{kW})$ and OP $(0.6 \mathrm{~kg} / \mathrm{kW})$ are scaled from their respective ISS PMAD equivalents. RFC mass, including ancillary equipment and heat rejection radiator, is $4.3 \mathrm{~kg} / \mathrm{kW}$-hr [3]. Power cabling mass is calculated based on run length, number of conductors, insulation type and Mil-W-22759D conductor mass properties. Thermal control heaters and radiators for PMAD components have not yet been factored into mass estimates. Mass margins are not applied.

\section{EPS PERFORMANCE ANALYSIS}

\section{POWER REQUIREMENTS}

Power requirements for an example 1130-day mission (with a single ISRU lander and a single crew surface habitat) are divided into two parts: (1) base loads, given in Table 1, and (2) an ISRU energy requirement. Base 
loads are required to operate ISRU ancillary equipment and all surface habitat equipment. These loads are divided by day/night and clear sky / dust storm (OD > 2) periods. The ISRU energy requirement, $400 \mathrm{MW}$-hr, is based on daytime only power consumption by ISRU primary equipment (CO2 intake compressor, Sabatier electrolysis reactor, zirconia electrolysis reactor, water electrolyzer) over a 435-day period. The ISRU plant is not operated during dust storms. The 435-day period represents the time between ISRU lander start-up and the crew trans-Mars injection burn. Power requirements are to be met at the power user interface, i.e. the output panels.

\section{COMPUTATIONAL METHODS}

A dedicated Fortran computer code was written to analyze EPS performance and calculate mass. The code runs on a SGI Indigo 2 work station. Most computational methods employed were borrowed from the EPS analysis code SPACE [39] developed by NASA for the ISS program. Nested iteration loops solve for PV array current, voltage and temperature in addition to PMAD system currents and voltages. A sophisticated iteration scheme allows for three EPS operating modes: (1) maximize minimum continuous power output while fully recharging the RFC energy storage every daily cycle, (2) fully recharge the RFC energy storage every day, over a set period of time, with either constant or variable electrolyzer current level and (3) discharge RFC energy storage to meet night-time load demand without always full daily recharge using either constant or variable electrolyzer current level. In all cases, energy balance is maintained and RFC minimum and maximum state-of-charge limits are satisfied. Based on time step sensitivity studies, a 0.5 -hour daily time step and a 5-sol mission time step are selected. For EPS operating mode (3), a mission time step of 1-sol is required for accurate solutions. These values provide a reasonable balance of solution accuracy/resolution and computer file size / run time for $1100-$ sol mission analysis runs.

\section{ENVIRONMENTS}

Several environments are important to operation of PV power systems on the surface of Mars. These environments are modeled within the Fortran computer codes and were evaluated hourly throughout the mission analysis. Environmental models include: dust storms, solar insolation and thermal conditions. It is assumed that two great dust storms occur every Martian year. Storm seasonal, temporal and spatial (versus landing site latitude) characteristics are described in [8]. Dust storm peak $O D$ was taken as the average of the lower limit of measured $O D$ and the estimated maximum $O D$ value for storms encountered by the Viking Landers [40]. This leads to a peak OD of about 6 , compared to 3.5 in [8], for the second dust storm at the Viking 1 landing site. $A$ peak $O D$ of 6 is consistent with that derived from lander pressure measurements [41] assuming use of a 0.79 value for dust particle, spectrum-averaged scattering asymmetry parameter from [40]. Relationships for Sun zenith angles, array solar incidence angles and the beam, diffuse and albedo components of solar insolation are given in $[8,42]$. Solar insolation components are based on a "net flux function" that is dependent on solar zenith angle and OD [9]. The net flux function describes the percentage of orbital solar insolation that is present within any layer of the atmosphere (including the planet surface). The net flux function is derived from computational solution of the radiative transfer equation via the "doubling method" $[43,44]$ that accounts for spectrally-dependent, multiple scattering and absorption. The accuracy of the net flux function method has been partially verified $[9,11]$ and further solar insolation data will be collected as part of the 2001 Mars Lander mission [45]. Mars heliocentric solar insolation is calculated based on aerocentric longitude of the Sun (Ls). Ls is calculated for each mission day based on the date, Mars ephemerides [14] and standard orbit mechanics.

The thermal environment is characterized by daily temperature profiles for the sky, illuminated ground and shadowed ground [46]. Temperature profiles are corrected for landing site latitude, Ls and OD. PV array degradation factors from other important environmental effects, such as dust accumulation, ultraviolet (UV) radiation and thermal cycling, were incorporated via data input files. With an effective dust abatement strategy incorporating tilted surfaces, low friction coatings and aeolian cleaning, the dust accumulation rate is assumed to be $5 \%$ of that measured by Pathfinder $[11,12]$. The actual dust abatement effectiveness of these methods and others will be measured as part of the Mars 2001 Lander Mission [24].

\section{PHOTOVOLTAIC ARRAYS}

PV array thermal-electrical performance is evaluated throughout the mission. Starting at the solar cell level, current-voltage (IV) response is modeled by a single exponential relationship based on four cell parameters (short-circuit current, open-circuit voltage and maximum power current and voltage). These cell parameters are corrected for temperature and environmental factors. Cell thermal response is based on a steady, lumpedparameter energy balance model. PV array tent temperatures are solved simultaneously based on a 3surface, diffuse enclosure radiation heat transfer problem formulation. The three surfaces are comprised of two PV array sections and the ground under the tent. Separate radiative exchange with illuminated and shadowed ground is modeled. Free and forced convection heat transfer components are small and can be ignored [46].

Cell IV operating point and temperature are iteratively determined. The solar cell string IV curve is determined by voltage addition of series-connected cells and 
accounting for the resistance of cell interconnects and power harness conductors. Correction factors were applied for solar insolation intensity, cell mismatch, array flatness, random array tilt (accounts for terrain slope or boulder field irregularity), solar pointing error and spectrum red-shift as a function of cell type, solar zenith angle and OD [47]. PV array section total current is determined by summing the parallel-connected string currents. Total PV array area is determined by the total cell area divided by the cell areal packing density, 0.9 . Losses from lander vehicle shadowing and terrain masking are not yet modeled pending better definitions of lander configuration and landing sites. However, for desirable near-equatorial landing sites (not in canyons), shadowing and terrain masking losses will be small. This is due to high sun angles (that create short shadows) and the large component of diffuse solar insolation near dusk and dawn (when the terrain masking effect is largest).

Cell IV parameters, temperature coefficients, optical properties and UV metastability (Staebler-Wronski effect in a-SiGe cells only) are obtained from and/or scaled from the following sources: a-SiGe cells $[25,48,49]$ and Culns2 cells $[30,31]$. UV and particle radiation darkening of adhesives, polymeric encapsulants [50] and substrates are implemented as time-dependent changes in solar absorptance, transmittance and thermal emittance. Contaminant losses are assumed small and not modeled.

\section{RFC ENERGY STORAGE}

Initial RFC electrical modeling is simply based on input energy efficiencies for the electrolyzer (0.9) and fuel cell (0.6) and an RFC system capacity rating, (660 amp-hr on ISRU lander and $4620 \mathrm{amp}-\mathrm{hr}$ on the surface habitat). Amp-hour capacity was selected to meet mission energy storage requirements using multiple, redundant RFC units. The minimum and maximum system state-ofcharge (SOC) values are set to 0.05 and 1.00 , respectively. SOC is based on amp-hour capacity which can be related to reactant tank operating pressures. Future models will include fuel cell and electrolyzer IV curves corrected for operating conditions and degradation effects. Proprietary PEM fuel cell stack life testing (4500 hours completed on a 10,000 hour endurance test) has shown essentially no degradation after operation at moderate and high current densities.

\section{POWER MANAGEMENT \& DISTRIBUTION}

All PMAD components are modeled as resistive and diode voltage losses or as converter/energy efficiency current/voltage losses based on ISS PMAD component performance. Power cables voltage drops are calculated based on specified resistance, operating temperature and run lengths. The small resistance of connectors is assumed to be accounted for in PMAD component resistances. PMAD component parasitic power loss and thermal control power are currently not modeled.

\section{RESULTS}

\section{TRADE STUDIES}

To guide EPS design, several trade studies were performed to quantify EPS sensitivity to a variety of unknowns. Trade studies included: launch opportunities, landing site latitude, number of yearly dust storms, PV array configuration and terrain slope angle.

EPS performance was calculated for the arrival dates associated with four Mars launch opportunities, 2009, 2011, 2013, and 2016. Compared to the baselined opportunity in 2011, EPS performance, as measured by ISRU energy, varied about $\pm 10 \%$. These variations were due to seasonal differences in solar flux, solar zenith angles, day/night periods and appearance of dust storms.

Landing site latitude effects Sun angles, surface solar intensity and opacity during dust storms. Higher latitudes have lower Sun angles with decreased available insolation. Dust storms are thought to originate at about $30^{\circ} \mathrm{S}$ latitude. Atmospheric opacity is highest at the dust storm origin and drops off for other latitudes. Over the accessible latitude range for human missions, $\pm 36^{\circ}$, EPS performance varies $+10 \% /-50 \%$ compared to that obtained at the equator. With the assumption of two great dust storms per year, the best performance is in the $15^{\circ}-20^{\circ} \mathrm{N}$ latitude range while the worst performance is obtained at $36^{\circ} \mathrm{S}$ latitude. EPS performance variation is maintained with $\pm 10 \%$ for landing sites between $10^{\circ} \mathrm{S}$ and $36^{\circ} \mathrm{N}$ latitude. Within this range, northern latitudes, with a lower average reference altitude and greater atmospheric density [14], would be preferred to improve aerobraking and parachute descent system performance and mass characteristics.

Because the likelihood of great dust storms on Mars is appreciable, the EPS must be designed for the worst case scenario, i.e. two great dust storms occur each Martian year. If, during the actual mission, fewer than two major storms occur, additional power or power margin will be available. EPS performance was calculated for cases with 0-2 dust storms per year. If there are no great dust storms during the mission, mission average user power would increase $35 \%$ while ISRU energy would increase $20 \%$.

EPS performance was calculated for several basic planar and tent PV array configurations. The two independent parameters were tilt angle, $0^{\circ}$ (flat on the ground) to $60^{\circ}$, and azimuth angle $\left(0^{\circ}\right.$ - South facing, $90^{\circ}$ - West facing). Because PV array power is a 
function of solar zenith angle (affects atmospheric losses), solar incidence angle (projected area loss) and operating temperature, the optimum PV array tilt for a given mission date and landing site, is not known a priori. For cases with equatorial facing arrays at $30^{\circ} \mathrm{N}$ or $30^{\circ} \mathrm{S}$ latitude, the optimum tilt angles occur in the $10^{\circ}-20^{\circ}$ range. This suggests there is a slight bias toward sky facing arrays to maximize collection of diffuse light over minimizing projected area loss, i.e. using a $30^{\circ}$ tilt angle. At the equator, array power is maximized using flat arrays. In all cases, array power exceeds that predicted using an average cosine loss. For example, an array tilted at $45^{\circ}$ produces over $75 \%$ of the power of a flat array whereas a $\sim 70 \%$ power fraction would be predicted. This is attributed to the major component of diffuse insolation (discussed later).

EPS performance with PV tent array tilt angles of $30^{\circ}$, $45^{\circ}$ and $60^{\circ}$ was calculated and compared with that from planar PV arrays. For all of these tilt angles, the tent arrays produced $5-10 \%$ more power than the planar arrays. The primary reason was that tent arrays operated $5-10^{\circ} \mathrm{C}$ cooler than the planar arrays due to lower back side heating fluxes. A $45^{\circ}$ tent array produced nearly $85 \%$ of the power a flat array.

The impact of tent array azimuth angle on EPS performance was also calculated. Azimuth angles were selected to allow array sections to face E-W, N-E-S-W and NE-SE-SW-NW. For a $45^{\circ}$ tent array, EPS performance varied only about $1 \%$ as function of azimuth. This result, for near equatorial landing sites, is attributed to the large diffuse component of solar insolation. Since EPS performance is not sensitive to deployed array section azimuth angles, requirements on landing vehicle touchdown attitude can be greatly relaxed.

When the PV arrays are deployed from the lander vehicle, the local terrain will not be perfectly flat. Instead, there will be a local slope and irregularities due to sand dunes or boulders. Several EPS analysis cases were run with various magnitudes of random terrain slope. Each array section was assigned a different random slope value less than or equal to a specified maximum slope limit. The random slope angle changed the PV array section effective tilt angle and created solar cell string current limiting loss due to varying solar incidence angle (conservative assumption). Martian terrain has been characterized by region to be smooth $(99 \%$ of slopes $\left.<8^{\circ}\right)$, nominal $\left(99 \%\right.$ of slopes $\left.<15^{\circ}\right)$ and rough $\left(99 \%\right.$ of slopes $\left.<30^{\circ}\right)$ [21]. By comparison, if a deployed PV array section rests on a 1-m high boulder lifting a span of $7 \cdot \mathrm{m}$ off the ground, an $8^{\circ}$ effective terrain angle is produced. For smooth and nominal terrain slopes, essentially no loss in EPS performance was predicted. For rough terrain, with $30^{\circ}$ maximum slopes, less than $5 \%$ of mission average user power was lost. This result again indicates the relative direction

NASA/TM-1999-209288 insensitivity of PV arrays operating on the Martian surface in the presence of diffuse solar and albedo fluxes.

\section{MISSION ANALYSIS}

Mission analysis cases were run assuming a 2011 launch opportunity. This places the ISRU lander on the surface of Mars on September 01, 2012 (Ls $=165^{\circ}$ or late Summer in the northern hemisphere) after a 298day, Type II Earth-Mars transfer trajectory. The assumed landing site, Site 021 Maja Valles, is at $18.95^{\circ}$ $\mathrm{N}$ lat, $-53.50^{\circ} \mathrm{W}$ long, and has an elevation of $-0.5 \mathrm{~km}$. For the given EPS configuration and mission characteristics, the number of PV array strings and the RFC capacity were iteratively adjusted until base load power requirements and ISRU energy requirements were met with a minimum sized EPS. Generally, the ISRU energy requirement determined the size of the PV array. RFC capacity was then selected to provide minimum state-of-charge (SOC) values between $5 \%$ (the lower limit) and $50 \%$ (engineering judgement). EPS operating mode (3) was used: that is, base loads were always met and the RFC was recharged for a fixed period of time at constant or variable current. RFC SOC was allowed to decrease day-to-day, if needed during dust storm periods.

A summary of EPS masses, performance and PV array areas is shown in Table 2. for a-SiGe and CulnS2 thin film cell options. To fully meet base load power requirements and the ISRU energy requirement, a 10.6 MT EPS and $\sim 6100 \mathrm{~m} 2 \mathrm{PV}$ array area was required assuming a-SiGe cell technology. A 10 MT EPS mass represents a very reasonable value for this class of ISRU lander vehicle. Nearly $70 \%$ of this EPS mass was attributed to the PV array. Averaged over the mission, this EPS delivered $46 \mathrm{~kW}$ to user loads and produced $107 \mathrm{~kW}$ average daytime PV array power. The resulting specific power figures of merit were $848 \mathrm{~W} / \mathrm{kg}$ (string power at $28^{\circ} \mathrm{C}$ with $1-$ Sun, AMO illumination divided by the array membrane mass), $46 \mathrm{~W} / \mathrm{kg}$ (maximum power at Mars surface operating conditions divided by the PV array mass) and $7 \mathrm{~W} / \mathrm{kg}$ (maximum user load power during operations divided by the EPS total mass). The specific power figure of merit changes by more than 100fold depending on what system power and mass values were chosen. This clearly illustrates the risk of using figures of merit in power system analyses with out explicit knowledge of the basis of such values.

By using the more advanced CulnS2 solar cell technology, EPS mass was reduced to 8.2 MT while the PV array area decreased to $\sim 4000 \mathrm{~m} 2$. Array area reduction was made possible by the higher conversion efficiency and UV stability (i.e. no Staebler-Wronski loss) of the CulnS2 cells compared to the a-SiGe cells. The EPS mass reduction was primarily attributed to the lighter array. The PMAD mass also decreased slightly 
given that peak component current levels were reduced. Specific power values were similar to those calculated for the a-SiGe technology with the exception of a higher membrane specific power, $1176 \mathrm{~W} / \mathrm{kg}$, compared to 848 W/kg.

The next series of figures shows Mars environment and EPS performance parameters throughout the 1130-day mission. Solar fluxes in Mars orbit and at the surface are shown in Figure 3. The orbital solar flux reflects the periodic intensity change associated with Mars heliocentric distance. The distinctive double dips in the surface flux curve correspond with the occurrences of yearly dust storms. Here the maximum surface insolation drops to $\sim 100 \mathrm{~W} / \mathrm{m} 2$ from a yearly average value of $\sim 450 \mathrm{~W} / \mathrm{m} 2$. Figure 4 shows the predicted atmospheric optical depth. At the $19^{\circ} \mathrm{N}$ latitude landing site, a peak optical depth of 6.3 is reached during the height of the second dust storm. Each dust storm lasts for over 100 days. Mars ground temperature and effective sky temperature curves are shown in Figure 5. The maximum daily ground temperature (upper curve) peaks under clear skies near mission day 500 (northern hemisphere Summer) when the Sun is highest overhead. At the same time, the sky temperature (lower curve) is at the lowest value as it responses to changes in orbital insolation that affects atmospheric heating. At the peak OD, environment temperatures become nearly isothermal at $\sim 200 \mathrm{~K}$.

Under these environmental conditions, the EPS power performance is shown in Figure 6 for tent array structures with CulnS2 solar cells. In this figure, the top curve is day-average PV array power, the middle curve is day-averaged user load power and the bottom curve is night time power. At mission day 1, day time user power exceeds $120 \mathrm{~kW}$ before falling off to $80 \mathrm{~kW}$ at the end of the mission. Throughout the mission, night time user power is set to the night time power requirement. In this analysis, "night time" is defined by the period (13 to 15.5 hours) when array power output is below the daytime power requirement. During dust storms, EPS capability falls off dramatically so that by mission day 900 , a daily energy balance can not be maintained. Under these conditions, the ISRU plant is placed in standby mode and the RFC energy storage is gradually discharged to meet base loads (to be discussed later). Mission energy tallies are shown in Figure 7. The bulk of user energy delivered is consumed by the ISRU plant during the first third of the mission. Thereafter, the EPS generates a large amount of excess energy that must be shunted or otherwise utilized. One attractive use for this excess energy is to produce $\mathrm{H}_{2}$ and $\mathrm{O}_{2}$ reactants from the available water cache. These reactants can then be used to boost EPS capability, generate life support water and reduce water reclamation system load during subsequent dust storms.
Figure 8 shows calculated PV array degradation factors and the resulting string current/voltage ratios normalized to reference values at $28^{\circ} \mathrm{C}, 1$-Sun illumination. String voltage capability during Mars surface operation (top curve) is improved over reference conditions due to low operating temperatures. String current capability (lower curve) is only $5 \%$ to $35 \%$ that of reference conditions. The drop in current capability results from reduced solar insolation, red-shift spectral response loss and dust obscuration loss.

PV array cell daily minimum and maximum operating temperatures are shown in Figure 9. Cell temperatures range between $10^{\circ} \mathrm{C}$ and $-100^{\circ} \mathrm{C}$ and closely follow environmental temperatures. The daily cell temperature range shrinks to only $\sim 30^{\circ} \mathrm{C}$ during dust storm activity. During these periods, ground temperatures cool off due to limited sunlight while the atmosphere absorbs much more energy and increases the effective sky temperature. During dust storm night periods, ground temperatures do not drop appreciable due to the warm, opaque atmosphere that blankets the surface.

The calculated, "in-service", daily solar cell efficiency range is plotted in Figure 10 . In this case, solar cell efficiency is defined by the product of operating current and voltage divided by the product of total front side solar insolation and cell area. Even though the reference cell efficiency is $18 \%$, the in-service efficiency averages from $-15 \%$ to $12 \%$ from mission beginning to end. The loss in efficiency reflects actual IV curve operating point and the environmental loss factors discussed above. On a given day, cell efficiency varies $3 \%$ due to changing temperature and red-shift spectral losses through the day time period. As in the situation with specific power figures of merit, using a reference cell efficiency in power system analysis can lead to inaccurate results. Accurate results are strongly dependent on properly determining expected solar cell operating conditions.

Figure 11. shows the RFC state of charge SOC. Throughout most of the mission, the SOC varies between 1.0 (fully charged condition; top curve) and 0.8 (bottom curve). Hence, only $15-20 \%$ of the energy storage capacity is being utilized. However, during the peak of the second dust storm pair, the RFC can no longer maintain energy balance while meeting the demands of base loads. Thus, RFC SOC falls off into the 0.4-0.5 range before the dust storm subsides.

The last group of figures show daily environmental and EPS performance parameters during the last day of the mission, sol 1100, prior to crew ascent from the Marian surface. Figure 12 illustrates eight components of daily solar flux on PV array section 5 (out of 8) during clear skies $(O D=0.5)$. The eight components are comprised of beam, diffuse, albedo and total insolation on the array 
segment front and back sides. Since this design incorporates tent arrays, the back side insolation components are zero. In this figure, time equal zero corresponds to local sunrise. Array section \#5 faces the North-East; a fact reflected in the beam and total insolation components (top two curves) that are slightly skewed toward the morning hours during more favorable solar incidence angles. The diffuse component (third curve from the top) is symmetrical with day time hour and peaks at local noon when the Sun is highest in the sky. The diffuse component accounts for $33 \%$ of the total insolation at noon, $50 \%$ of the total insolation 1 -hour after sunrise and $100 \%$ on the insolation 1-hour before sunset. The albedo component (bottom curve) is also symmetrical with respect to day hour, but contributes little to the total insolation on the array section front side. Under dust storm conditions with $O D=3.0$, the total insolation is $90 \%-100 \%$ comprised of the diffuse insolation component. This large component of diffuse solar insolation during clear skies and dust storms accounts for the relatively insensitive directional dependence of PV array performance under Martian surface illumination conditions.

Daily temperatures for solar cells on 4 out of 8 PV array sections is shown in Figure 13. Temperatures range from $8^{\circ} \mathrm{C}$ to $-82^{\circ} \mathrm{C}$ and follow trends in environment temperatures and solar heating. Eastward facing array sections 5 and 7 reach maximum temperatures in the late morning while westward facing sections, 1 and 3 , attain peak temperatures in the early afternoon.

For these daily temperature and illumination conditions, the array section power profiles produced are shown in Figure 14. Power profiles mimic the daily illumination profiles. Discontinuities in the power profile occur in the morning and afternoon, for example section \#7 at time = 11 hours. The discontinuities are created when the beam insolation component goes to zero. When diffusely illuminated, array section power changes more slowly versus time and local Sun angle.

Finally, Figure 15 shows the daily variation in total PV array power and user power. Both array power and user power follow a skewed cosine profile throughout the day. The RFC electrolyzer is turned on for 8-hours of daily operation. This results in a rapid $10 \mathrm{~kW}$ change in user power at time $=2.5$ hours and time $=11.0$ hours. Most of this daily "user" power goes to the ISRU plant which must tailor its operations to accommodate this power profile. Preliminary ISRU plant operating strategies are being developed to investigate ways to best utilize the available power. The first such strategy judiciously switched ISRU components on/off for several hour blocks of time and made use of $73 \%$ of available energy. The technical challenges for this kind of strategy include plant control and component reliability with accumulated start-stop cycles.

\section{CONCLUSION}

Based on conceptual designs and detailed performance analyses, we have developed a credible solar EPS option that satisfies the surface power requirements of a human Mars mission. This option employs a $10 \mathrm{MT}$ class EPS with a $5000 \mathrm{~m} 2$ class deployable array using thin film solar cell technology.

\section{CONTACT}

Thomas $W$. Kerslake is an aerospace engineer in the Power \& Propulsion Office. Phone 216-433-5373. Email kerslake@grc.nasa.gov

\section{REFERENCES}

1. Drake, B. G., Cooke, D. A., "Reference Mission Version 3.0 Addendum to the Human Exploration of Mars: The Reference Mission of the NASA Mars Exploration Team Study," NASA Publication EX1398-036, June 1998.

2. McKissock, Barbara I., et al., "A Solar Power System for an Early Mars Expedition," NASA TM 103219, 1990.

3. Withrow, Colleen A and Morales, Nelson, "Solar-Electrochemical Power System for a Mars Mission," NASA TM 106606, Dec 1994

4. Landis, Geoffrey A... "Solar Cell Selection For Mars." $2^{\text {na }}$ World Cont. on Photovoltaic Solar Energy Conversion, Vienna, Austria, Vol. 3, Jul 6-10, 1998, p. 3695-3698.

5. Perez-Davis, Marla E., et al., "Lunar and Martian environmental interactions with nuclear power system radiators," NASA-TM-105747, Aug 01, 1992.

6. Zurek, Richard W. and Martin, Leonard J., "Interannual Variability of Planet-Encircling Dust Storms on Mars," J. Geo. Res., Vol 98, No E2, 1993, p. 3247-3259

7. Martin, Leonard J., and Zurek, Richard W., "An Analysis of the History of Dust Activity on Mars," J. Geo. Res., Vol 98, No E2, 1993. p. 3221-3246.

8. Appelbaum, Joseph and Landis, Geoffrey A., "Solar Radiation on Mars-Update 1991," NASA TM 105216, 1991.

9. Pollack, James B., et al., "Simulations of the General Circulation of the Martian Atmosphere: 1. Polar Processes," J. Geo. Res., Vol 95, No B2, 1990, p. 1447-1473.

10. Landis, G., "Dust Obscuration of Mars Photovoltaic Arrays," paper IAF-94-380, Acta Astronautica, Vol. 38, No. 11, 1996, p. 885-891.

11. Appelbaum, Joseph, et al., "Verification of Mars Solar Radiation Model Based on Pathfinder Data," NASA TM 113167, 1997.

12. Jenkins, P., et al., "Materials Adherence Experiment: Technology," 32nd Intersociety Energy Conversion Engineering Conference, paper 97339, Aug 1997.

13 Scheiman, David A., et al., "Low Intensity, Low Temperature (LILT) Measurements on New Photovoltaic Structures," 30th Intersociety Energy Conversion Engineering Conference, paper 95353, Aug 1995. 14. Kaplan, David I., "Environment of Mars, 1988," NASA TM 100470. Oct 1988, pp. 2-10.

15. Ryan, J. A. and Henry, R. M., "Mars Atmospheric Phenomena During Major Dust Storms, as Measured at the Surface," Journal of Geophysical Research, Vol 84, No B6, Jun 10, 1979.

16 Kolecki, Joseph C., "Electrostatic Charging of the Mars Pathfinder Rover and Charging Phenomena on the Planet Mars," 32th Intersociety Energy Conversion Engineering Conference, paper 97344, Aug 1997.

17. Simonsen, Lisa C., et al., "Radiation Exposure for Manned Mars Surface Missions," NASA TP 2979, Mar 1990.

18. Simonsen, Lisa C. and Nealy, John E., "Mars Surface Radiation Exposure for Solar Maximum Conditions and 1989 Solar Proton Events," NASA TP 3300, Feb 1993. 
19. Colozza, Anthony J., "Design and Optimization of a Self-Deploying PV Tent," NASA CR 187119, June 1991.

19. http://www.aec-able.com/corporate/articula.htm

21. Plescia, Jeffrey B., "Viking 2 Landing Site: Site Description and Material Properties," Jet Propulsion Laboratory, Pasadena, California, circa 1991.

22. Gaier, James R. and Perez-Davis, Marla E., "Aeolian removal of dust types from photovoltaic surfaces on

Mars," 16th Space Simulation Conference Confirming Spaceworthiness Into the Next Millennium, Nov 01, 1990, p. 379-396.

23. Landis, G. A., "Mars Dust-Removal Technology," Journal of Propulsion and Power, Vol. 14, No. 1, Jan-Feb 1998, p. 126-128.

24. Landis, G. A., et al., "Dust Accumulation and Removal Technology (DART) Experiment on the Mars 2001 Surveyor Lander," $2^{\text {no }}$ World Conf. on Photovoltaic Solar Energy Conversion, Vienna, Austria,

Vol. 3, Jul 6-10, 1998, p. 3699-3702.

25. Jang, Jeffrey, et. al., "Recent Progress in Amorphous Silicon Alloy Leading to $13 \%$ Stable Cell Efficiency," $26^{\text {th }}$ IEE PVSC, Anaheim, CA, Sep 29- Oct 3, 1997

26. Nakatani, K., et al., Applied Physics Letters, Vol. 54, 1989, p. 1678.

27. Hanak, J. J. and Kaschmitter, "The status of lightweight photovoltaic space array technology based on amorphous silicon solar cells," Space Photovoltaic Research and Technology Conference, 1991

28. Hanak, J. J., et al., "Ultralight Amorphous Silicon Alloy Photovoltaic Modules for Space Applications," Space Photovoltaic Research and Technology (SPRAT) Conference, 1986, p. 99-110.

29. Hanak, J. J., Proc. IEEE Photovoltaic Specialists Conf. 1985, p. 89

30. Bulent, M. Basol. et al., "Light-Weight, Flexible Thin Film Solar Cells for Space Applications," NASA CR 195466., Jun 1995.

31. Mitchell, K.W., et al., "7.3\% Efficient CulnS2 Solar Cell," $18^{\text {m }}$ IEEE Photovoltaic Specialists Conference, 1988, p. 1542-1544.

32. Landis, Geoffrey A., and Hepp, Aloysius F., "Applications of ThinFilm Photovoltaics for Space," 36th Intersociety Energy Conversion Engineering Conference, Aug 1991, p. 256-261.

33. Ramanathan, K., et al., "High-Efficiency Cu(ln,Ga)Se2 Thin Film Solar Cells Without intermediate Buffer Layers," $2^{\text {ns }}$ World Conf. on Photovoltaic Solar Energy Conversion, Vienna, Austria, Vol. 1, Jul 6-10, 1998, p. 477-481.

34. Kerslake, Thomas W., and Gefert, Leon P., "Solar Power System Analyses for Electric Propulsion Missions," , 34th Intersociety Energy Conversion Engineering Conference, paper 99106, Aug 1999.

35. Science Applications International Corporation, "Final Report: Deployable Photovoltaic Arrays," NAS3- 26565, SAIC Subcontract 4600000188, SDRL 002, 24 Feb 1999

36. Appelbaum, Joseph, et al., "Solar Radiation on Mars: Tracking Photovoltaic Array, NASA TM 106700, Sep 1994.

37. George, Patrick, "Space Solar Power Technology Plan FY 99: Power Management and Distribution," NASA Lewis Research Center, 1998.

38. Katzan, Cynthia M. and Edwards, Jonathon L.., "Lunar Dust Transport and Potential Interactions With Power System Components," NASA CR 4404, Nov 1991.

39. Hojnicki, J. S., et al., "Space Station Freedom Electrical Performance Model," 28th Intersociety Energy Conversion Engineering Conference Proceedings, Atlanta, Georgia, 1993.

40. Pollack, James B., et al., "Properties and Effects of Dust Particles Suspended in the Martian Atmosphere," J. Geo. Res., Vol 84, No B6, Jun 10, 1979, p. 2929-2945.

41. Zurek, Richard W., "Martian Great Dust Storms: An Update," Icarus, Vol. 50, May-Jun 1982, p. 288-310.

42. Appelbaum, J., et al., "Solar Radiation on Mars: Stationary Photovoltaic Array," NASA TM 106321, Oct 1993.

43. Hansen, James E., "Radiative Transfer By Doubling Very Thin Layers," The Astrophysical Journal, Vol. 155, Feb 1969.

44. Hansen, James E., "Multiple Scattering of Polarized Light in Planetary Atmospheres: Part I. The Doubling Method," Journal of the Atmospheric Sciences, Vol. 28, Sep 1970.
45. Scheiman, David A., et al., "Mars Array Technology Experiment (MATE) For the Mars 2001 Lander," $2^{\text {nd }}$ World Conf. on Photovoltaic Solar Energy Conversion, Vienna, Austria, Vol 3., Jul 6-10, 1998, p. $3675-3678$

46. Matz, E., et al., "Solar Cell Temperature on Mars," Journal of Propulsion and Power, Vol. 14, No. 1, Jan-Feb 1998.

47. Burger, Dale R., "Mars Solar Array Program," Jet Propulsion Laboratory, NAS7-918, 1993.

48. Boswell, J., et al., "Thin Film Photovoltaic Development at Phillips Laboratory," 23 $3^{\text {rd }}$ IEEE Photovoltaic Specialists Conference, 1993, p. $1324-1329$

49. Byvik, C. E., et al., "Radiation Damage and Annealing of Amorphous Silicon Solar Cells," $14^{\text {th }}$ IEEE Photovoltaic Specialists Conference, 1984, p. 155-160.

50. Zuby, Thomas M., et al., "Degradation of FEP Thermal Control Materials Returns form the Hubble Space Telescope," NASA TM 104627, Dec 1995

\begin{tabular}{|c|c|c|c|c|c|}
\hline \multirow{2}{*}{$\begin{array}{c}\text { Mission } \\
\text { Day }\end{array}$} & \multicolumn{2}{|c|}{ Clear Skies } & \multicolumn{2}{c|}{ Dust Storm } & $\begin{array}{c}\text { ISRU } \\
\text { Energy } \\
\text { (MW-hr) }\end{array}$ \\
\cline { 2 - 6 } & Day & Night & Day & Night & 400 \\
\hline $0-435$ & 7 & 2 & 4 & 2 & 400 \\
\hline $436-630$ & 9 & 3 & 4 & 2 & 0 \\
\hline $631-1130$ & 18 & 7 & 15 & 6 & 0 \\
\hline
\end{tabular}

Table 1. Power Requirements (kW)

\begin{tabular}{|l|c|c|}
\hline \multicolumn{1}{|c|}{ Parameter } & $\alpha$-SiGe & CulnS2 \\
\hline Power Levels (kW) & & \\
BOL to User: Day / Night & $168 / 2$ & $130 / 2$ \\
Mission Average to User & 46 & 40 \\
Mission Average PV Array & 107 & 92 \\
\hline EPS Mass (MT) & & \\
PV Array & 7.2 & 5.0 \\
RFC & 1.3 & 1.3 \\
PMAD & $\underline{2.1}$ & 1.9 \\
Total & 10.6 & 8.2 \\
\hline Specific Power (W/kg) & & \\
Membrane Panel & 848.4 & 1176.5 \\
PV Array & 46.7 & 47.4 \\
EPS & 7.5 & 7.6 \\
\hline Total PV Array Area (m2) & 6153 & 4013 \\
\hline No. Cells per String & 330 & 860 \\
\hline Total No. of Strings & 6712 & 1680 \\
\hline \multicolumn{2}{|r}{ Table } \\
\hline
\end{tabular}

Table 2. EPS Sizing Results

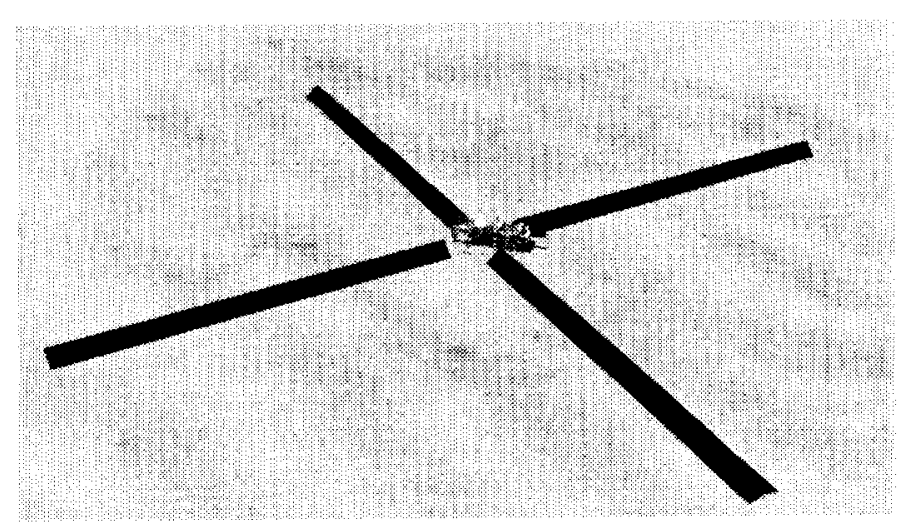

Figure 1a. Mars Surface PV-RFC Power System (Far View) 


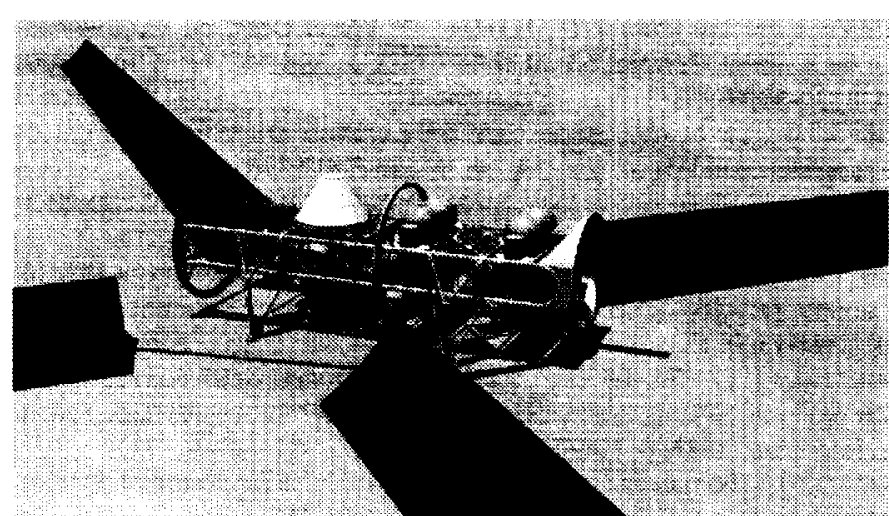

Figure 1b. Mars Surface PV-RFC Power System (Close-Up View)

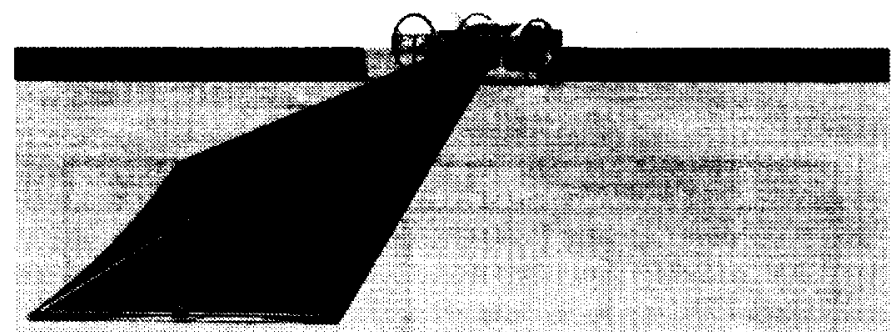

Figure 1c. Mars Surface PV-RFC Power System (Ground Level View )

(Shown With Array Triangular End Panel Removed)

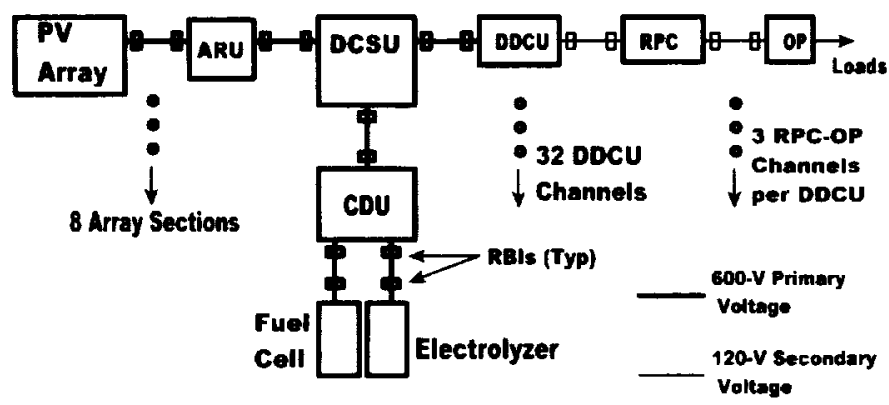

Figure 2. PMAD Architecture

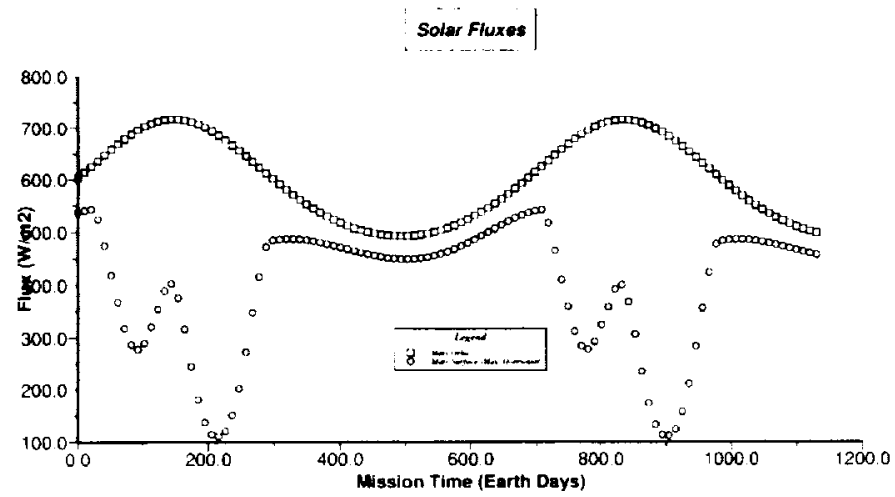

Figure 3. Solar Fluxes

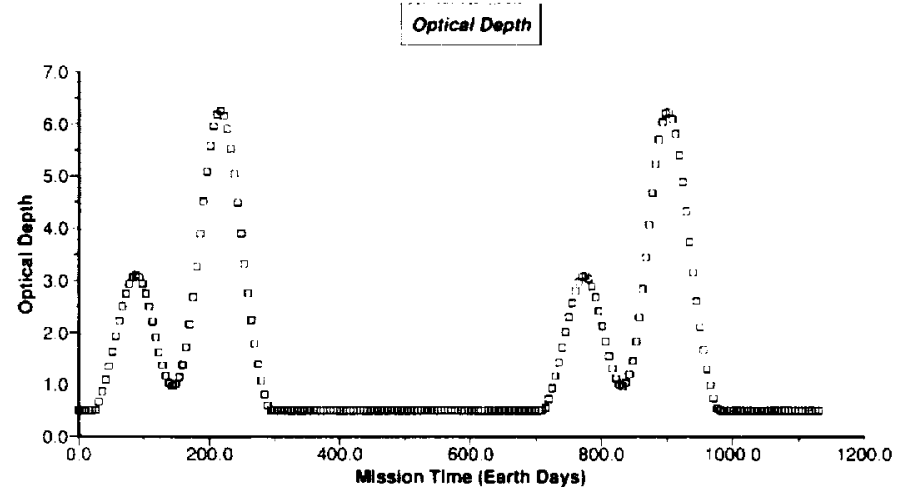

Figure 4. Optical Depth

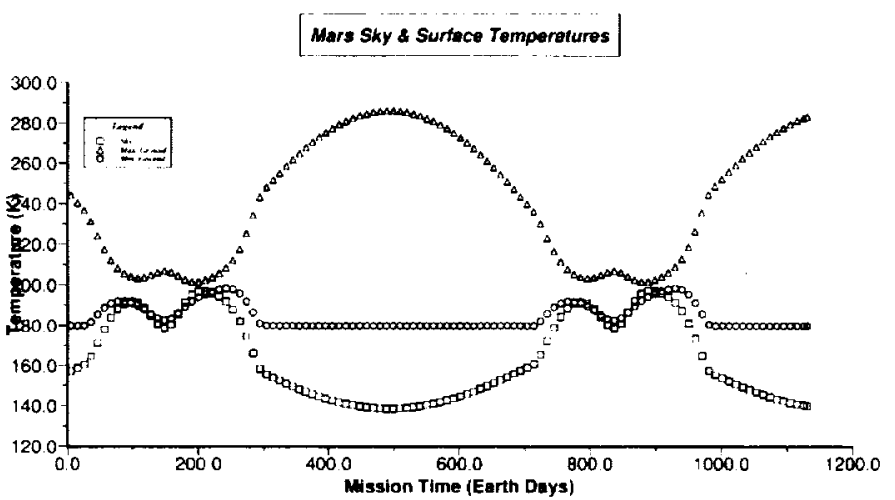

Figure 5. Environment Temperatures

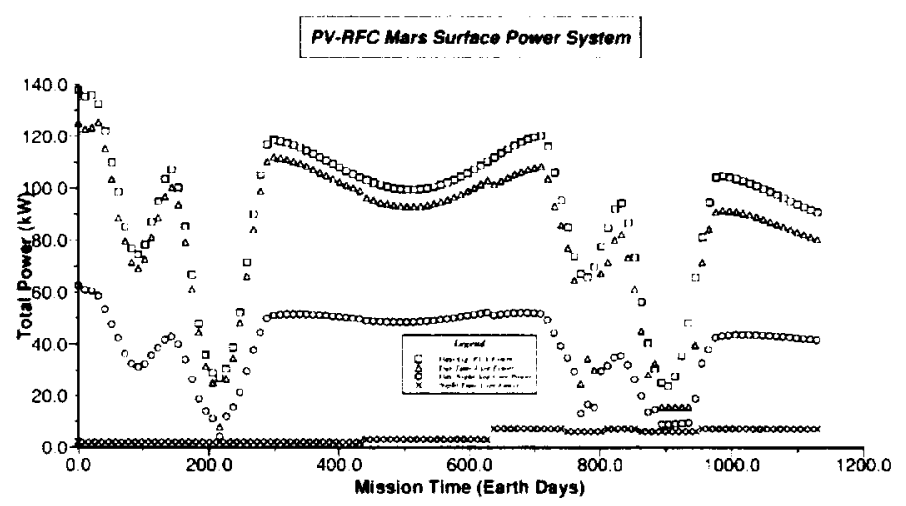

Figure 6. PV Array and User Power

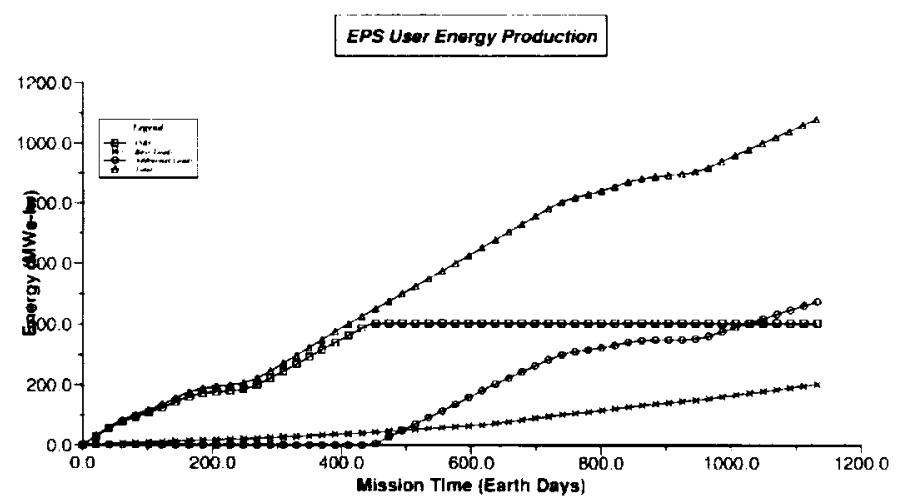

Figure 7. EPS Mission Energy 


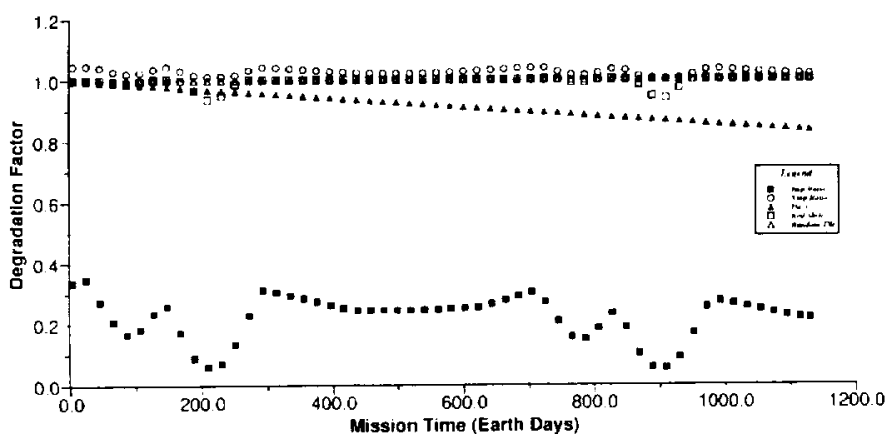

Figure 8. PV Array Degradation

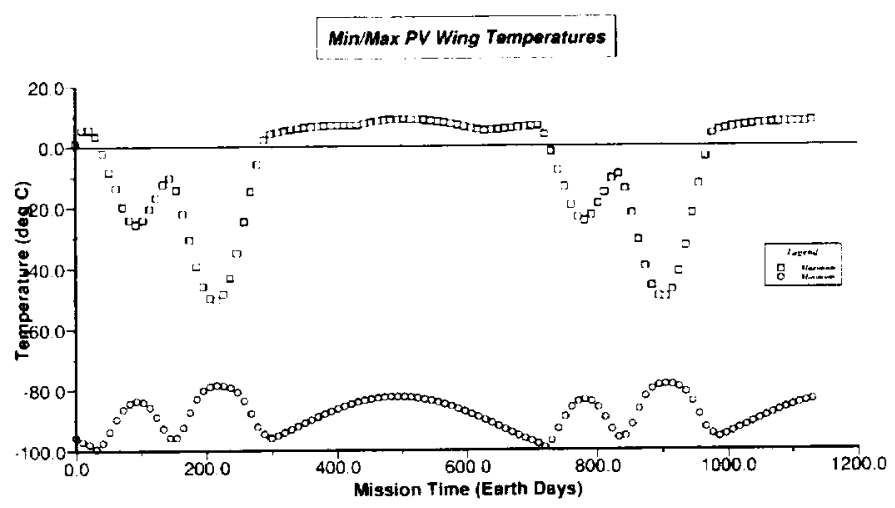

Figure 9. PV Array Minimum/Maximum Temperatures

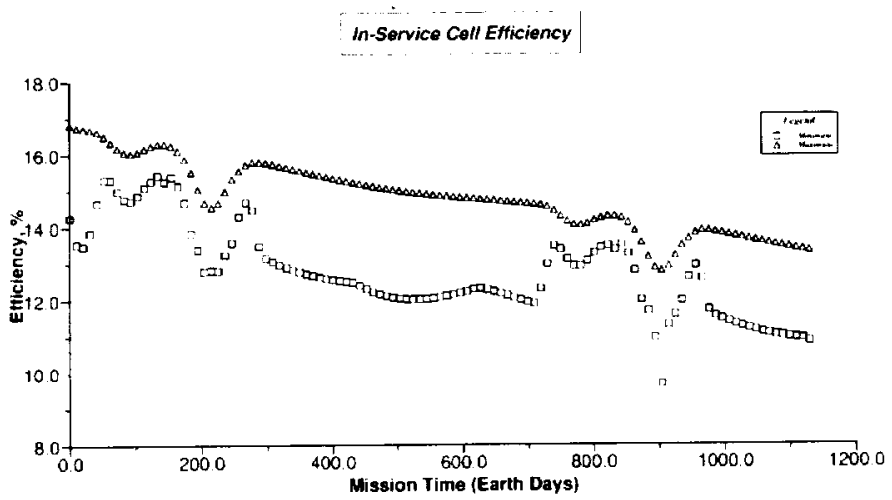

Figure 10. In-Service Cell Efficiency

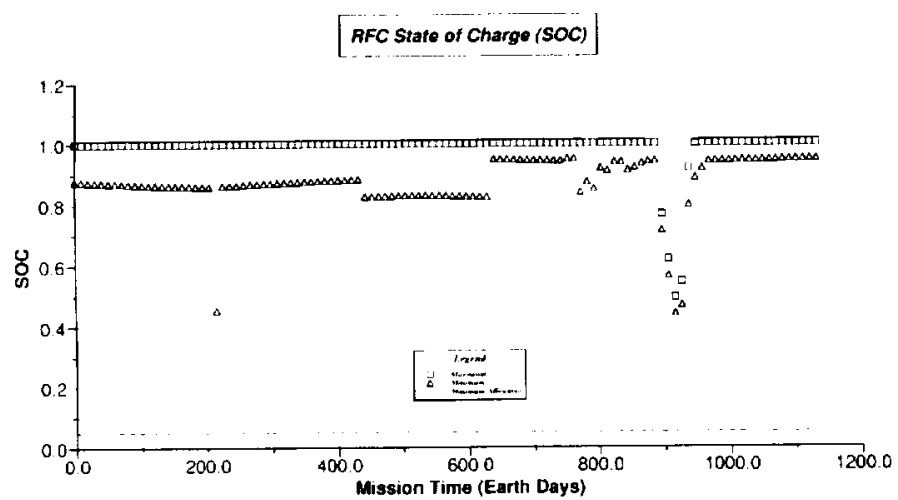

Figure 11. RFC State-of-Charge

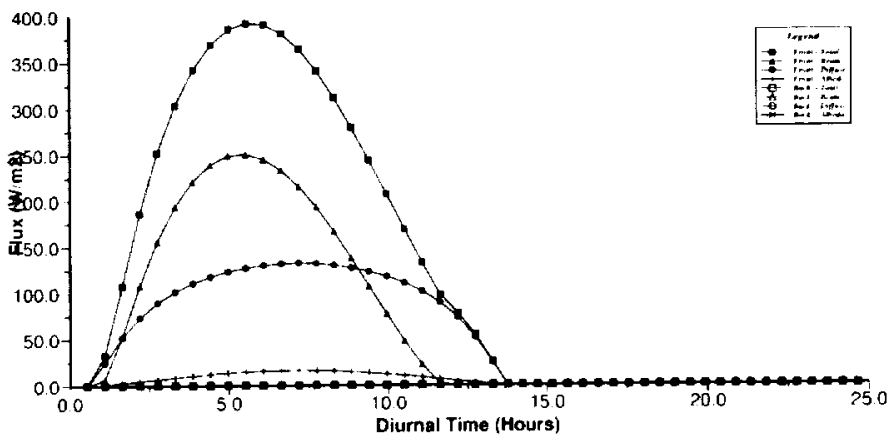

Figure 12. Daily Solar Fluxes on PV Array Section \#5 (faces North-East) at 1100 sols

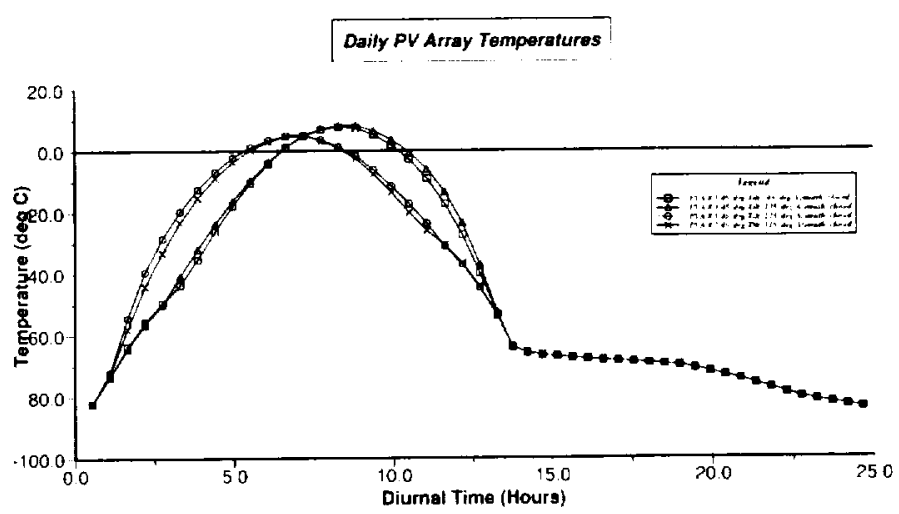

Figure 13. Daily PV Array Temperatures at 1100 sols

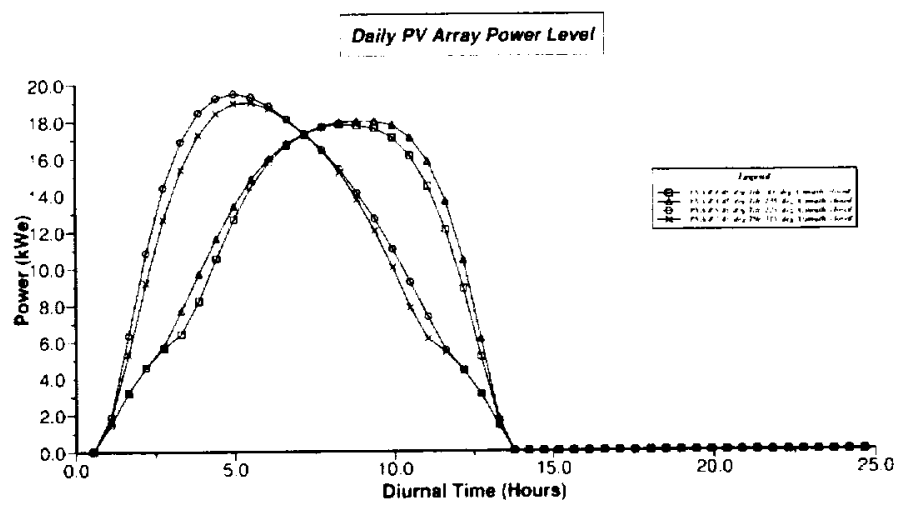

Figure 14. Daily PV Array Section Power at 1100 sols

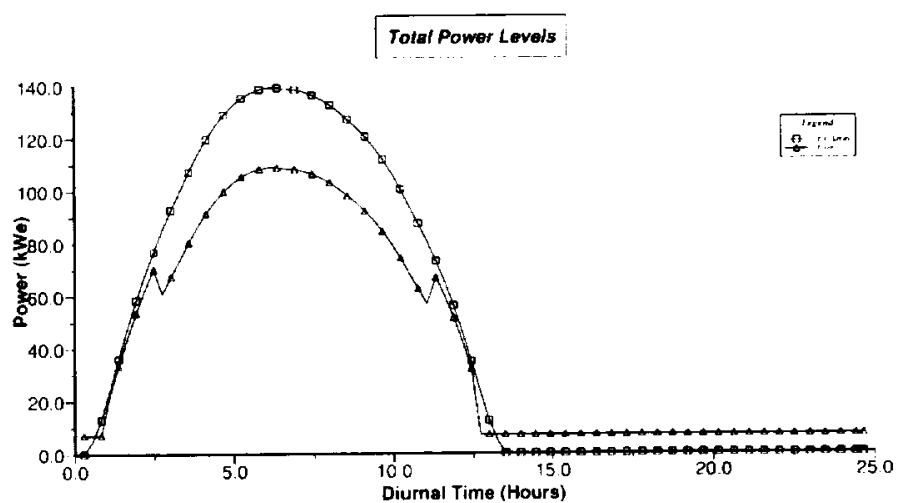

Figure 15. Daily Total PV Array and User Power at 1100 sols 
Public reporting burden tor this collection of information is estimated to average 1 hour per response, including the time for reviewing instructions, searching existing data sources, gathering and maintaining the data needed. and completing and reviewing the collection of information. Send comments regarding this burden estimate or any other aspect of this collection of information, including suggestions for reducing this burden, to Washingion Headquarters Services, Directorate for information Operations and Feports, 1215 Jefferson Davis Highway. Suite 1204. Arlington, VA 22202-4302, and to the Office of Management and Budget. Paperwork Reduction Project (0704-0188), Washington. DC 20503.

\begin{tabular}{|l|c|c|}
\hline 1. AGENCY USE ONLY (Leave blank) & $\begin{array}{r}\text { 2. REPORT DATE } \\
\text { July } 1999\end{array}$ & $\begin{array}{r}\text { REPORT TYPE AND DATES COVERED } \\
\text { Technical Memorandum }\end{array}$ \\
\hline
\end{tabular}

4. TITLE AND SUBTITLE

Solar Electric Power System Analyses for Mars Surface Missions

6. AUTHOR(S)

$$
\text { WU }-6.32-1 \mathrm{~A}-1 \mathrm{X}-00
$$

Thomas W. Kerslake and Lisa L. Kohout

-

\section{PERFORMING ORGANIZATION NAME(S) AND ADDRESS(ES)}

National Acronautics and Space Administration

John H. Glenn Research Center at Lewis Field

Cleveland. Ohio 44135-3191

8. PERFORMING ORGANIZATION

REPORT NUMBER

E-11758

\section{SPONSORING/MONITORING AGENCY NAME(S) AND ADDRESS(ES)}

National Aeronautics and Space Administration

Washington, DC 20546-0001

10. SPONSORING/MONITORING AGENCY REPORT NUMBER

NASA TM-1999-209288

SAE 99-()1-2482

\section{SUPPLEMENTARY NOTES}

Prepared for the 34th Intersociety Energy Conversion Engineering Conference sponsored by the Society of Automotive Engineers, Vancouver, British Columbia, Canada, August 1-5, 1999. Responsible person. Thomas W. Kerslake, organization code $6920,(216) 433-5373$.

12a. DISTRIBUTION/AVAILABILITY STATEMENT 12b. DISTRIBUTION CODE

Unclassified - Unlimited

Subject Categories: 18 and 20

Distribution: Nonstandard

This publication is available from the NASA Center for AeroSpace Information. (301) 621-0390.

13. ABSTRACT (Maximum 200 words)

The electric power system is a crucial element of any architecture supporting human surface exploration of Mars. In this paper, we describe the conceptual design and detailed analysis of solar electric power system using photovoltaics and regenerative fuel cells to provide surface power on Mars. System performance, mass and deployed area predictions are discussed along with the myriad environmental factors and trade study results that helped to guide system design choices. Based on this work, we have developed a credible solar electric power option that satisfies the surface power requirements of a human Mars mission. The power system option described in this paper has a mass of $\sim 10$ metric tons, a $\sim 50(0)-\mathrm{m} 2$ deployable photovoltaic array using thin film solar cell technology.

\section{SUBJECT TERMS}

Solar arrays: Electric power; Mars bases; Mars exploration; Mars environment: Design analysis; Manned Mars missions

\begin{tabular}{|c|c|}
\hline $\begin{array}{c}\text { 17. SECURITY CLASSIFICATION } \\
\text { OF REPORT } \\
\text { Unclassified }\end{array}$ & $\begin{array}{c}\text { 18. SECURITY CLASSIFICATION } \\
\text { OF THIS PAGE } \\
\text { Unclassified }\end{array}$ \\
\hline
\end{tabular}

NSN 7540-01-280-5500

15. NUMBER OF PAGES 17

16. PRICE CODE $\mathrm{A03}$

SECURITY CLASSIFICATION OF ABSTRACT

Unclassified 